\title{
The regulation of BK channel activity by pre- and post-translational modifications
}

\section{Barry D. Kyle and Andrew P. Braun*}

Department of Physiology and Pharmacology, Cumming School of Medicine, Libin Cardiovascular Research Institute, University of Calgary, Calgary, AB, Canada

\section{Edited by:}

Alex M. Dopico, The University of Tennessee Health Science Center, USA

\section{Reviewed by:}

Carmen Valenzuela, Instituto de Investigaciones Biomédicas CSIC-UAM, Spain

Luis MS Loura, University of Coimbra, Portugal

\section{*Correspondence:}

Andrew P. Braun, Department of Physiology and Pharmacology, Cumming School of Medicine,

University of Calgary, 3330 Hospital Drive NW, Calgary, AB T2N 4N1,

Canada

e-mail: abraun@ucalgary.ca
Large conductance, $\mathrm{Ca}^{2+}$-activated $\mathrm{K}^{+}(\mathrm{BK})$ channels represent an important pathway for the outward flux of $\mathrm{K}^{+}$ions from the intracellular compartment in response to membrane depolarization, and/or an elevation in cytosolic free $\left[\mathrm{Ca}^{2+}\right]$. They are functionally expressed in a range of mammalian tissues (e.g., nerve and smooth muscles), where they can either enhance or dampen membrane excitability. The diversity of BK channel activity results from the considerable alternative mRNA splicing and post-translational modification (e.g., phosphorylation) of key domains within the pore-forming $\alpha$ subunit of the channel complex. Most of these modifications are regulated by distinct upstream cell signaling pathways that influence the structure and/or gating properties of the holo-channel and ultimately, cellular function. The channel complex may also contain auxiliary subunits that further affect channel gating and behavior, often in a tissue-specific manner. Recent studies in human and animal models have provided strong evidence that abnormal BK channel expression/function contributes to a range of pathologies in nerve and smooth muscle. By targeting the upstream regulatory events modulating BK channel behavior, it may be possible to therapeutically intervene and alter BK channel expression/function in a beneficial manner.

Keywords: calcium-activated $\mathrm{K}^{+}$channel, $\beta$ subunit, phosphorylation, modulation, smooth muscle, neuron, contractility

\section{INTRODUCTION: BK CHANNEL DISTRIBUTION AND ARCHITECTURE}

BK channels, also called MaxiK/Slo1/ $\mathrm{K}_{\mathrm{Ca}} 1.1$ channels, are a class of $\mathrm{K}^{+}$ion channels that undergo extensive pre- and posttranslational modification. BK channel $\alpha$ subunits are encoded by the KCNMA1 gene, also known as $S L O$, and are ubiquitously expressed throughout mammalian tissues (e.g., neurons, smooth and skeletal muscles, exocrine cells). BK channels are assembled and strategically positioned on membrane surfaces, including the plasma membrane (Latorre et al., 1989), mitochondria and nucleus (Singh et al., 2012). Functional BK channels are multimeric structures composed of four similar pore-forming $\alpha$ subunits (Shen et al., 1994) and up to four regulatory $\beta$ subunits can co-assemble with the tetrameric $\alpha$ subunit complex. The synergistic activation of $\mathrm{BK}$ channels by $\mathrm{Ca}^{2+}$ ions and depolarization causes a substantial $\mathrm{K}^{+}$current that exhibits a large or "big" single channel conductance (i.e., up to $250 \mathrm{pS}$ under symmetric $\mathrm{K}^{+}$ conditions). Activation of this formidable ionic current serves to drive membrane potential in the negative direction.

The transmembrane portion of the BK channel $\alpha$ subunit structure is thought to largely resemble that of voltage-gated $\mathrm{K}^{+}\left(\mathrm{K}_{\mathrm{v}}\right)$ channel subunits in terms of voltage-sensing and poreforming domains. Notably, BKa subunits contain an additional transmembrane segment, termed S0, resulting in an extracellular N-terminus. Specialized charged residues are present within the transmembrane segments $\mathrm{S} 2-\mathrm{S} 4$ of the $\mathrm{BK \alpha}$ subunit that contribute to its voltage-sensing properties. While topologically similar to their $K_{v}$ channel counterparts, BK channels display weaker or less sensitive voltage-dependent activation (i.e., the ionic conductance-voltage relation is less steep), due to an altered distribution of voltage-sensing residues within the S2-S4 segments (Ma et al., 2006). Mechanistically, membrane depolarization drives conformational re-arrangements in the voltage sensor domains, resulting in an upward twisting of the $\mathrm{S} 4$ segment relative to the pore domain; these conformational movements are reversed upon repolarization (Hoshi et al., 2013).

The C-terminal domain of the $\mathrm{BK} \alpha$ subunit contains a considerable range of specialized structures that regulate channel function. These include several binding sites for divalent cations (i.e., $\mathrm{Ca}^{2+}$ and $\mathrm{Mg}^{2+}$ ) and regions that undergo dynamic posttranslational modification such as phosphorylation. Each mammalian $\mathrm{BK} \alpha$ subunit contains two "regulators of $\mathrm{K}^{+}$conductance" (RCK) domains, arranged in tandem along the $\mathrm{C}$-terminus; in the tetrameric channel complex, these RCK domains co-assemble to form an octomeric gating ring structure in the cytosol (Yuan et al., 2010). The RCK domains also have $\mathrm{Ca}^{2+}$-binding regions and are crucial in conferring the channel's $\mathrm{Ca}^{2+}$ ion sensing properties (Cui et al., 2009). $\mathrm{Ca}^{2+}$ ions bind to these specialized regions within the $\mathrm{BK} \alpha \mathrm{C}$-terminus, leading to a structural expansion of the intracellular region of the ion conduction pathway that facilitates gating and $\mathrm{K}^{+}$efflux (Yuan et al., 2012; Hoshi et al., 2013).

\section{GENETIC DIVERSITY AND SPLICE VARIANTS}

Unlike the $\mathrm{K}_{\mathrm{v}}$ channel superfamily, which uses different genes to increase its genetic diversity, BK channels derive functional 
diversity through the alternative post-transcriptional splicing of mRNA derived from the single KCNMA1 gene encoding the $\mathrm{BK} \alpha$ subunit (Shipston, 2001). Up to ten distinct splice sites have been described in KCNMA1 (Poulsen et al., 2009), leading to the generation of $\mathrm{BK} \alpha$ subunits with different phenotypes and various functional roles, including altered sensitivity to $\mathrm{Ca}^{2+}$ and/or voltage (Shipston, 2001; Johnson et al., 2011), responses to phosphorylation (Tian et al., 2001), signaling cascades (Schubert and Nelson, 2001; Tian et al., 2001, 2004), membrane expression regulation (Alioua et al., 2008; Ahrendt et al., 2014), trafficking and lipidation (Toro et al., 2006; Zarei et al., 2007; Shipston, 2014). The impressive range of phenotypic products that can result from differential splicing of the KCNMA1 gene product contributes to diversity of BK channel function between tissues, cells and intracellular compartments.

\section{BK CHANNEL AUXILIARY SUBUNITS}

BK channels can co-assemble with modulatory auxiliary subunits BKß1-4 (Knaus et al., 1994a; Tanaka et al., 1997; Brenner et al., 2000a; Uebele et al., 2000), as well as a newly defined family of leucine-rich repeat containing subunits (LRRCs), referred to as $\gamma$ subunits (Yan and Aldrich, 2010, 2012). Both BK $\beta$ and $\gamma$ subunits contain sizeable extracellular regions and it is thought that these regions physically interact with the membrane-spanning domains of the $\mathrm{BK} \alpha$ subunit. In particular, $\mathrm{BK} \beta$ subunits appear to interact mainly with the N-terminal S0-S2 segments of the pore-forming $\mathrm{BK} \alpha$ subunit (Morrow et al., 2006; Liu et al., 2008; Morera et al., 2012), thereby regulating channel opening through allosteric effects on the intramolecular processes underlying $\mathrm{Ca}^{2+}$ and/or voltage-dependent activation. As these auxiliary subunits are expressed in a tissue-specific manner, they confer distinct functional consequences by impacting BK channel kinetics and gating behavior. For instance, BK $\beta 1$ subunits are typically expressed in smooth muscle, whereas $\mathrm{BK} \beta 4$ are expressed in neural tissue. BK $\beta$ subunits 1, 2 and 4 are reported to stabilize the channel's voltage sensor domains in the active conformation (Contreras et al., 2012), thereby enhancing channel activity, In contrast, $\mathrm{BK} \beta 2$ and $\beta 3$ subunits confer BK channel inactivation via an $\mathrm{N}$-terminal "inactivation ball" (Wallner et al., 1999; Brenner et al., 2000a; Uebele et al., 2000) (Figure 1), which will limit $\mathrm{K}^{+}$efflux and membrane hyperpolarization. To date, two functionally-distinct $\mathrm{BK} \beta 2$ splice variants $\left(\mathrm{BK} \beta 2_{\mathrm{a}-\mathrm{b}}\right)$ have been described in mammals, although $\mathrm{BK} \beta 2_{\mathrm{b}}$ does not appear to inactivate the channel complex (Ohya et al., 2010). Similarly, four functionally-distinct $B K \beta 3$ splice variants $\left(B K \beta 3_{\mathrm{a}-\mathrm{d}}\right)$ are known, with splice variants $\mathrm{A}-\mathrm{C}$ conferring partial inactivation of $\mathrm{BK}$ channel current (Uebele et al., 2000). BK $\beta 4$ subunits are the most distantly-related of the $\beta$ subunits in terms of sequence similarity and produce mixed effects on $\mathrm{BK}$ channel gating, depending on the local $\mathrm{Ca}^{2+}$ concentration. At low $\mathrm{Ca}^{2+}$ concentrations, BK $\beta 4$ appears to decrease channel activation, but at high $\mathrm{Ca}^{2+}$ concentrations, activation is enhanced (Brenner et al., 2000a; Wang et al., 2006).

The molecular mechanisms by which $\gamma$-subunits interact with and influence $\mathrm{BK}$ channel gating and kinetics are currently an area of active investigation. All four known LRRC proteins (i.e., LRRC26, 38, 52, and 55) have been reported to enhance voltage-dependent activation of BK channels (Yan and Aldrich, 2010, 2012), with LRRC26 producing an impressive shift of up to $-150 \mathrm{mV}$.

\section{ROLE OF BK CHANNELS IN SMOOTH MUSCLE FUNCTION AND DISEASE}

Phasic smooth muscles, such as those lining the urinary bladder, urethra and ureters, undergo action potential (AP) events, with rapid depolarization-repolarization fluctuations. APs cause

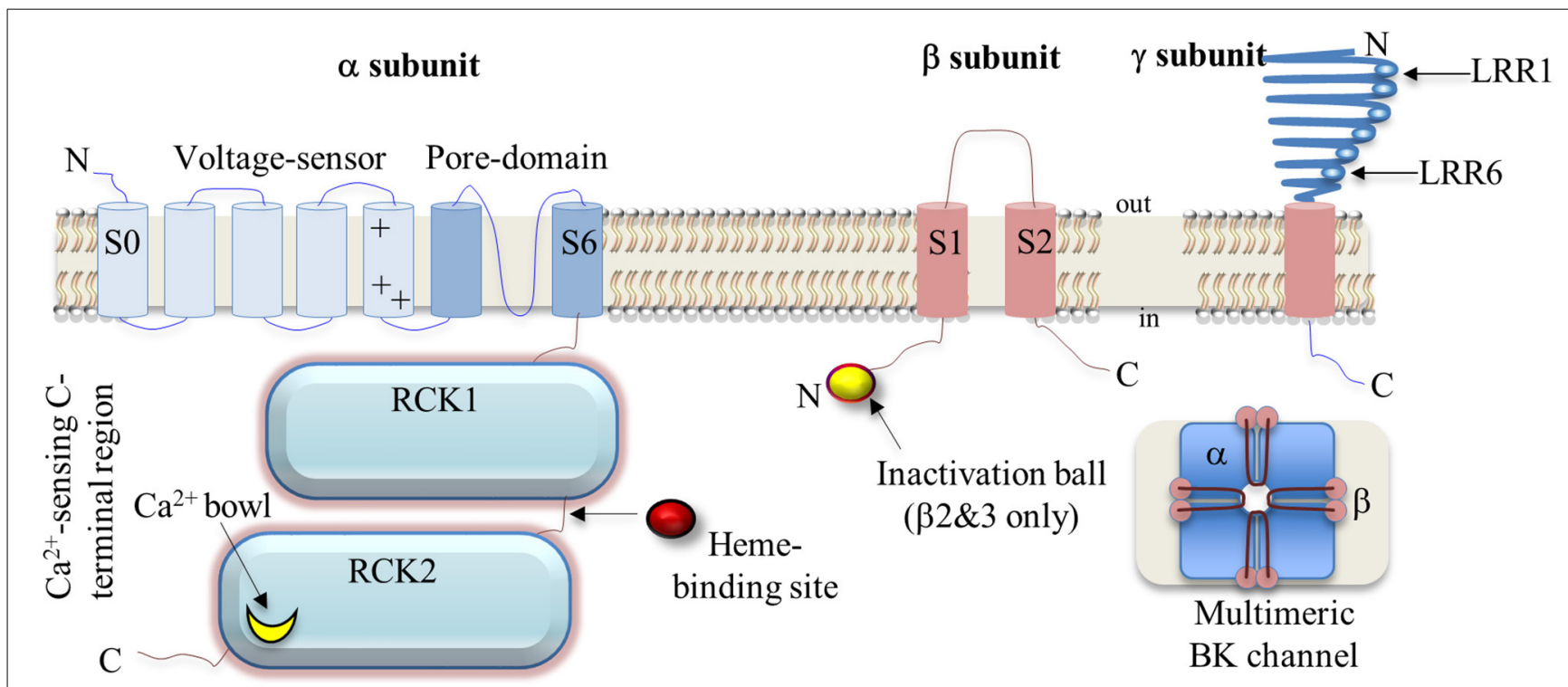

FIGURE 1 | A schematic illustration of BK channel $\alpha, \boldsymbol{\beta}$ and $\boldsymbol{\gamma}$ subunit architecture with major structures defined. Abbreviations: $\mathrm{N}$, amino-terminus; $\mathrm{C}$, carboxy-terminus; LRR, leucine-rich repeat; $S$, transmembrane segment; RCK, regulator of $\mathrm{K}^{+}$conductance. 
a significant global increase in intracellular $\left[\mathrm{Ca}^{2+}\right]$ and $\mathrm{BK}$ channels are largely responsible for the rapid down-stroke (repolarization) phase (Burdyga and Wray, 2005; Thorneloe and Nelson, 2005; Kyle et al., 2013b). In contrast, tonic smooth muscles, such as those found throughout vascular tissue and much of the gastrointestinal tract and airways, regulate lower magnitude changes in membrane potential by principally responding to localized elevations in intracellular $\left[\mathrm{Ca}^{2+}\right]$ mediated by ryanodine receptors (RyRs) (Figure 2). The dynamic post-translational "tuning"

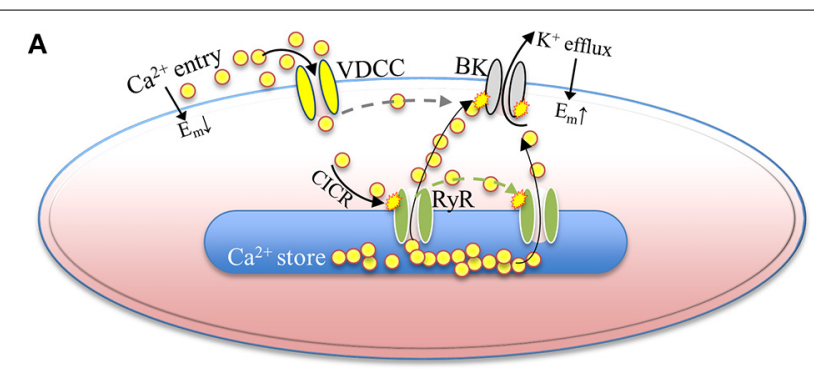

B

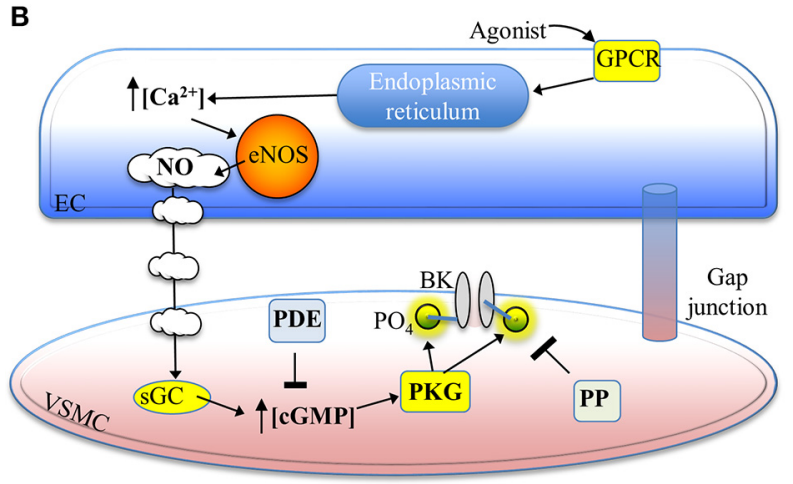

FIGURE 2 | A summary of select physiological mechanisms leading to BK channel activation and reversible phosphorylation-mediated enhancement. (A) $\mathrm{Ca}^{2+}$-dependent activation of $\mathrm{BK}$ channels hyperpolarizes the membrane potential. Depolarization of the membrane potential activates voltage-dependent $\mathrm{Ca}^{2+}$ channels, leading to $\mathrm{Ca}^{2+}$ entry and $\mathrm{Ca}^{2+}$-induced $\mathrm{Ca}^{2+}$ release from nearby ryanodine receptors. Released $\mathrm{Ca}^{2+}$ promotes $\mathrm{BK}$ channel activation, which drives the membrane potential in the negative (hyperpolarized) direction. $\mathrm{Ca}^{2+}$ influx via VDCCs may also contribute directly to BK channel activation (dotted line) as a result of the spatial proximity of these two channels within membrane nano/micro-domains. (B) Mechanisms underlying the generation of nitric oxide from an endothelial cell, with the NO/cGMP/PKG-mediated phosphorylation of a BK channel illustrated in an adjacent vascular smooth muscle cell. Nitric oxide release from endothelial cells binds to soluble guanylyl cyclase in smooth muscle cells, resulting in elevated intracellular cGMP concentrations. PKG is then activated and phosphorylates the BK $\alpha$ subunit. Phosphodiesterase activity lowers intracellular cGMP and protein phosphatase activity removes the regulatory phosphate from Ser/Thr residues of the BK channel protein. Abbreviations: VDCC,

voltage-dependent $\mathrm{Ca}^{2+}$ channel; $\mathrm{BK}, \mathrm{BK}$ channel; $\mathrm{E}_{\mathrm{m}}$, membrane potential; $\mathrm{CICR}, \mathrm{Ca}^{2+}$-induced $\mathrm{Ca}^{2+}$ release; RyR, ryanodine receptor; GPCR, GTP-binding protein-coupled receptor; eNOS, endothelial nitric oxide synthase; NO, nitric oxide; EC, endothelial cell; sGC, soluble guanylyl cyclase; PDE, phosphodiesterase; $\mathrm{PO}_{4}$, phosphate group; cGMP, cyclic guanosine monophosphate; PKG, protein kinase G; PP, protein phosphatase; VSMC, vascular smooth muscle cell. of BK channels permits considerable diversity in the biophysical properties of the current.

In common with many other tetrameric $\mathrm{K}^{+}$channels in smooth muscles, the amplitude of $\mathrm{K}^{+}$current carried through BK channels in smooth muscles can be dynamically regulated by post-translational modifications to the channel complex, including the reversible phosphorylation of the pore-forming $\mathrm{BK} \alpha$ subunit by a number of protein kinases, as described below. Almost all phosphorylation sites are conserved in mammalian BK channel splice variants.

Many tissues have distinct macromolecular signaling complexes underlying the function of ion channels. Smooth muscles, for instance, generally have closely-associated RyRs, which periodically release $\mathrm{Ca}^{2+}$ and cause local elevations in $\left[\mathrm{Ca}^{2+}\right]_{\mathrm{i}}$ (i.e., 10-20 MM) (Pérez et al., 1999; ZhuGe et al., 2002) near BK channels positioned on the plasma membrane, which is sufficient to significantly raise the $\mathrm{P}_{\mathrm{o}}$ and efflux $\mathrm{K}^{+}$(Figure 2). The RyRs themselves are often close to $\mathrm{Ca}^{2+}$ influx pathways, for instance voltage-gated $\mathrm{Ca}^{2+}$ channels, or in proximity to $\mathrm{IP}_{3}$ receptors (Ohi et al., 2001).

The primary role of BK channels in vascular smooth muscle (VSM) is to repolarize/hyperpolarize the cell membrane potential in the face of chronic depolarizing stimuli, thereby reducing contractile activity. It is now well-recognized that enhancement of BK channel current in VSM via phosphorylation is principally-regulated by nitric oxide (NO)/cGMP/PKG signaling (Feil et al., 2003) (see Section BK Channel Modulation via Protein Phosphorylation below). NO is a gaseous second messenger synthesized mainly by the adjacent endothelial cell layer lining the lumen of all blood vessels (Fleming and Busse, 2003). Therefore, BK channel activity is considered to be closely linked with endothelial cell activity. Therapeutically, NO and synthetic NO donors are used to treat a range of vascular disorders, including angina pectoris and hypertension (Wimalawansa, 2008).

In addition to the urinary tract and VSM, BK channels are also important regulators in mediating the proper function of various other smooth muscles, including those found in the gastrointestinal tract, airway, and uterus. Their function, however, varies between cell types and layers, and generally is dependent on the associated macromolecular signaling complex. In the colon, for instance, BK channels contribute to setting the resting membrane potential in longitudinal smooth muscle, whereas in the circular layer, they limit excitatory responses (Sanders, 2008).

In VSM, a single amino acid polymorphism in the BK $\beta 1$ subunit (i.e., E65K) is reported to have a gain-of-function effect on BKs channel activation and has been associated with lower systolic and diastolic blood pressures and a decreased prevalence of diabetic hypertension in humans (Fernández-Fernández et al., 2004; Nielsen et al., 2008). In contrast, BK $\beta 1$ subunit expression is decreased in some forms of genetic hypertension (Amberg and Santana, 2003). Moreover, a point mutation (R140W) in the BK $\beta 1$ subunit that modestly impairs channel opening has been linked with asthma severity in African-American males (Seibold et al., 2008). Provocative data from Jaggar and colleagues further suggest that the majority of $\mathrm{BK} \beta 1$ subunits reside within the cell interior and assemble with $\alpha$ subunits at the cell surface in a dynamic fashion (Leo et al., 2014). NO signaling appears 
to promote the forward trafficking of internal $B K \beta 1$ subunits to the cell membrane, where they co-associate with $\mathrm{BK} \alpha$ subunits to enhance channel activation. The authors suggest that auxiliary $\mathrm{BK} \beta 1$ subunits undergo selective endocytosis from the plasma membrane, followed by re-insertion in response to a vasodilatory stimulus, such as NO. These data imply that native BK channels in VSM may not always contain a full complement of $\beta 1$ subunits (i.e., the ratio of $\beta 1$ to $\alpha$ subunits in a single channel complex is $<1$ ), as described in rat cremaster artery (Yang et al., 2009), and that the subunit stoichiometry of these channels is not permanent. Dynamic regulation of BK channel subunit co-assembly and interaction at the plasma membrane may thus represent a novel paradigm for the modulation of ion channel activity.

Many research groups have reported that BK channel activity is upregulated during hypertension, and its contribution is apparently enhanced compared to normotensive animals (for review, see Joseph et al., 2013). It should be noted, however, that downregulation of $\mathrm{BK}$ channel activity has also been reported during hypertension (Amberg et al., 2003; Amberg and Santana, 2003; Nieves-Cintrón et al., 2007; Yang et al., 2013). Investigators have speculated that this decrease may be due to reduced $\mathrm{BK} \beta 1$ subunit expression/coupling, which would dampen the $\mathrm{Ca}^{2+}$ sensitivity of BK channel activation. Several research groups have reported that BK current density is positively-correlated to blood pressure in hypertensive animals (Rusch et al., 1992; England et al., 1993; Rusch and Runnells, 1994; Liu et al., 1998). Aortic smooth muscle isolated from rats with renal hypertension, spontaneously-hypertensive rats (SHR) and stroke-prone SHR (Rusch et al., 1992; England et al., 1993; Liu et al., 1998) exhibits significantly-upregulated BK channel activity, likely as a compensatory response. Collectively, these studies indicate that the expression and function of BK channels in the vasculature involves complex expression and signaling pathways, and may vary between cells, tissues, vascular beds and pathophysiological profiles.

BK channels are densely-expressed in mammalian bladder tissues ( $\sim 20$ channels per square micrometer) (Ohi et al., 2001) with $\mathrm{BK} \beta 1$ auxiliary subunits. $\mathrm{BK} \alpha$ subunit knockout mice have demonstrated bladder dysfunction and exhibit a depolarized resting membrane potential in isolated bladder smooth muscle cells and intact tissues, indicating a role for BK channels in setting the membrane potential (Sprossmann et al., 2009). Inhibition of BK channel current with iberiotoxin in the bladders of healthy mice led to similar effects (Heppner et al., 1997; Hristov et al., 2011). BK $\beta 1$-knockout mice similarly display overactive bladder symptoms, and a significant decrease in BK channel activity (Petkov et al., 2001). Intriguingly, bladder smooth muscle tissue taken from patients with neurogenic bladder over-activity exhibit little to no response to $\mathrm{BK}$ channel inhibition by iberiotoxin, or the channel agonist NS1619, indicating severe BK channel dysfunction (Oger et al., 2010). Macroscopic current recordings from these tissues demonstrated a significantly lower BK channel current density that mirrors that reported for experimentallyinduced partial urethral obstruction in rats (Aydin et al., 2012). Patients with benign prostatic hyperplasia experiencing overactive bladder symptoms also demonstrate a parallel reduction in BK channel expression (Chang et al., 2010). Overexpression of
BK channel protein in rats with experimentally-induced partial urethral obstruction proved to be an effective treatment for the existing overactive bladder activity (Christ and Hodges, 2006). These data collectively indicate that BK channels are important regulators of bladder smooth muscle excitability, and a potential target for therapeutic intervention for overactive bladder conditions.

\section{ROLE OF BK CHANNELS IN NEURONAL FUNCTION/DYSFUNCTION}

BK channels are abundantly expressed in both central and peripheral neurons, with prominent expression reported in both the cell body and pre-synaptic terminals (Faber and Sah, 2003). Functionally, these channels are key regulators of neuronal excitability, as channel opening will reduce action potential (AP) amplitude and duration, increase the magnitude of the fast afterhyperpolarization (fAHP) immediately following repolarization and limit the frequency of AP burst firing (Bielefeldt and Jackson, 1993; Faber and Sah, 2003; Gu et al., 2007; Haghdoost-Yazdi et al., 2008). At the pre-synaptic nerve terminal, localized BK channel activity can modulate both the amplitude and duration of depolarization-evoked $\mathrm{Ca}^{2+}$ entry as a result of the rapid repolarization and deactivation of voltage-gated Cav 2.1 (i.e., P/Q-type) and 2.2 (N-type) $\mathrm{Ca}^{2+}$ channels (Robitaille and Charlton, 1992; Issa and Hudspeth, 1994; Marrion and Tavalin, 1998; Fakler and Adelman, 2008). Reduced $\mathrm{Ca}^{2+}$ influx will limit vesicle fusion at active zones, leading to decreased neurotransmitter release (Roberts et al., 1990; Hu et al., 2001; Raffaelli et al., 2004).

Dissecting the functional roles of BK channels in the nervous system has been greatly aided by the availability of highly selective toxins (i.e., iberiotoxin) (Kaczorowski and Garcia, 1999) and small molecule inhibitors (e.g., penitrem A, paxilline, lolitrem B) (Knaus et al., 1994b; Imlach et al., 2008; Nardi and Olesen, 2008), along with the generation of genetically-engineered mice lacking either BK $\alpha$ or $\beta$ subunits (Brenner et al., 2000b, 2005; Plüger et al., 2001; Meredith et al., 2004; Sausbier et al., 2004). Such strategies have revealed that the loss of neuronal BK current, either acutely or chronically, increases membrane excitability by decreasing the magnitude of the fAHP. Reducing the fAHP facilitates more rapid membrane depolarization in response to a tonic stimulus, leading to higher frequency AP firing. Such alterations in neuronal activity are typically associated with neurological disorders in the CNS, including tremor and ataxia (Sausbier et al., 2004; Brenner et al., 2005; Imlach et al., 2008). Interestingly, a point mutation in the RCK1 domain of the BK $\alpha$ subunit (i.e., D434G) identified in a subset of epileptic patients has been shown to increase neuronal BK channel activity by enhancing $\mathrm{Ca}^{2+}$-dependent channel gating (Du et al., 2005; Wang et al., 2009; Yang et al., 2010). Functionally, increasing BK activity and the associated fAHP may augment membrane excitability in the soma by enhancing the recovery rate of fast $\mathrm{Na}^{+}$currents from voltage-dependent inactivation and reducing the absolute refractory period of neuronal firing.

In the CNS of mice and humans, genetic knockout or mutational disruption of the molecular chaperone cysteine string protein $(\mathrm{CSP} \alpha)$ is linked with early onset neurodegeneration (Fernandez-Chacon et al., 2004; Donnelier and Braun, 2014), 
and interestingly, these conditions are associated with a significant up-regulation of $\mathrm{BK}$ channel expression in mouse brain and cultured neurons (Kyle et al., 2013a; Ahrendt et al., 2014). Although the mechanistic link between increased BK expression/activity and neurodegeneration remains undefined, it is hypothesized that increased BK current density in pre-synaptic terminals and/or the soma may lead to disrupted synaptic membrane excitability and neurotransmitter release. As described below, elevated BK channel expression in the CNS is closely linked with epilepsy, strongly suggesting that increased BK current density can lead to neurological disorders and possibly synaptic dysfunction/degeneration.

\section{POST-TRANSLATIONAL MODIFICATION}

Heteromeric BK channel complexes are the subject of extensive post-translational modifications, which can significantly alter channel behavior. Some modifications are highly-complex and require prior upstream modification(s) to the channel subunits.

\section{BK CHANNEL MODULATION VIA PROTEIN PHOSPHORYLATION}

Perhaps the most studied enzymatically-driven modification of $\mathrm{BK}$ channels is the addition of phosphate $\left(\mathrm{PO}_{4}^{3-}\right)$ groups to functionally-important residues (Ser/Thr/Tyr) present within the channel's pore-forming $\alpha$ subunit. These reactions are catalyzed by select protein kinases and are reversed by the actions of protein phosphatases that dephosphorylate these sites following removal of the stimulus. Phosphorylation can be either stimulatory or inhibitory with respect to the open probability of the channel and can depend on several variables (see below).

Regulation of BK channel activity in smooth muscles by phosphorylation-dependent signaling pathways is well documented (Schubert and Nelson, 2001) and the main modifying enzymes include cAMP- and cGMP-dependent protein kinases (i.e., PKA and PKG, respectively), protein kinase C (Zhou et al., 2010) along with c-Src tyrosine kinase (Davis et al., 2001). Biochemically, PKA is comprised of 2 catalytic and 2 regulatory subunits and kinase activation occurs in response to the direct binding of the second messenger cAMP to the regulatory subunits (Taylor et al., 1990). Cyclic AMP synthesis occurs following stimulation of adenylyl cyclase by hormones (e.g., adenosine, $\beta$ adrenergic agonists, $\mathrm{PGI}_{2}, \mathrm{PGE}_{2}$, etc.) or direct activators (e.g., forskolin). In the case of PKG activation, synthesis of cGMP can occur via a soluble or a membrane-bound form of guanylyl cyclase (Münzel et al., 2003); the former is typically activated by $\mathrm{NO}$ and the latter by natriuretic peptides acting on the cell surface receptors NPR-A and NPR-B. Structurally, PKG exists as a homodimer in which each monomer consists of a regulatory and catalytic domain linked in a single polypeptide chain (Francis et al., 2010); holo-PKG thus closely resembles the overall structure of PKA. Generally, PKA and PKG-mediated phosphorylation leads to BK channel enhancement, whereas PKC leads to channel inhibition. It should be stressed, however, that these regulatory effects on BK channel activity depend upon contextual phosphorylation/modification at multiple sites (Zhou et al., 2010, 2012; Kyle et al., 2013c), and may be further influenced by the constitutive phosphorylation status of the channel complex (see below). Selective blockade of the phosphodiesterase enzymes responsible for cGMP metabolism by pharmacologic agents such as sildenafil will prolong cGMP effects in smooth muscle and this process has been exploited therapeutically to treat erectile dysfunction and pulmonary hypertension (Francis et al., 2010). For a comprehensive overview of early studies describing BK channel regulation by kinase-associated pathways, see Schubert and Nelson (2001).

Using a multi-faceted strategy involving protein biochemistry, site-directed mutagenesis and patch clamp recordings, our group has recently reported that NO/cGMP/PKG signaling in VSM cells leads to the modification of three distinct Ser residues in the $\mathrm{BK} \alpha$ C-terminus (i.e., Ser 691, 873 and 1111-1113), which directly correlate with enhancement of channel activity (Kyle et al., 2013c). Not unexpectedly, one of these sites (i.e., Ser873) is also important for PKA-mediated enhancement of BK activity (Nara et al., 1998). The regulatory phosphorylation status of BK channels also appears to differ developmentally, as BK channels in fetal arteries display more enhanced activity compared with channels from adult VSM (Lin et al., 2005, 2006). Augmentation of BK channel activity by $\mathrm{NO} / \mathrm{cGMP} / \mathrm{PKG}$ signaling is readily reversible and this is largely due to dephosphorylation via Ser/Thr protein phosphatases. Several studies have described involvement of protein phosphatases 1 and $2 \mathrm{~A}$ in the regulation of BK channel activity, based mainly on the selective actions of inhibitors, such as okadaic acid (Zhou et al., 1996, 2010; Sansom et al., 1997).

Activation of PKC is reported to inhibit BK channel activity in VSM via the putative phosphorylation of Ser695 and Ser1151, and these modifications also appear to interfere with the stimulatory effects mediated by PKA and PKG (Zhou et al., 2010). Interestingly, this PKC-mediated inhibition of channel activity is absent in STREX-containing BK $\alpha$ splice variants (Zhou et al., 2012) (see below).

Similar to VSM, neuronal BK channel activity can be enhanced in response to regulatory phosphorylation of the pore-forming $\mathrm{BK} \alpha$ subunit by both PKA and PKG, which can be reversed by the actions of Ser/Thr phosphatases 1 and 2A (Reinhart et al., 1991; Reinhart and Levitan, 1995; Sansom et al., 1997; Tian et al., 1998). Interestingly, proteomic analyses of rat brain BK channels isolated under basal conditions has identified $\sim 30$ Ser and Thr residues that appear to be constitutively phosphorylated in vivo, with 23 of these modified residues located within the channel's C-terminus (Yan et al., 2008). Such observations suggest that constitutive phosphorylation may help stabilize BK channel tertiary structure and/or create binding sites for interacting proteins. The various protein kinases responsible for these in vivo modifications are presently unknown, as is the extent to which channels from other tissues or expressed heterologously exhibit constitutive phosphorylation. Our recent data describing a role for multiple phosphorylation sites to support cGMP-dependent augmentation of BK channel activity in VSM cells (Kyle et al., 2013c) promote the idea that individual phospho-Ser/Thr residues act synergistically to enhance BK channel activity.

In neurons and neuroendocrine cells (e.g., pituitary, adrenal gland) and more recently in VSM (Nourian et al., 2014), a portion of BK channels identified by qRT-PCR contain the STREX splicing insert, a 59 amino acid insert present at splice site C2 within the C-terminus (Xie and McCobb, 1998; Shipston, 2001). In response to cAMP/PKA signaling, a Ser residue within the STREX 
insert can undergo phosphorylation, which has been shown to decrease BK channel activity (Tian et al., 2001). Functionally, such a change would be expected to enhance membrane excitability in neuroendocrine cells and promote exocytosis. Interestingly, phosphorylation of the STREX domain also appears to override the positive gating effects mediated by PKA-induced phosphorylation at other C-terminal sites, leading to an overall dominantnegative effect of STREX phosphorylation on BK channel activity (i.e., a single STREX-containing $\alpha$ subunit within a tetrameric channel is sufficient to flip PKA-mediated phosphorylation from stimulatory to inhibitory) (Tian et al., 2004). Furthermore, this inhibitory effect of PKA on BK channel activity appears to depend upon the presence of palmitoyl fatty acid groups within the STREX insert (Shipston, 2014), as palmitoylation-incompetent BK channels do not undergo PKA-mediated phosphorylation of the STREX insert and a decrease in activity (Tian et al., 2008). Collectively, these findings suggest that presence of STREX insert will lead to association of a C-terminal domain with the plasma membrane, which appears necessary for PKA-mediated phosphorylation within the STREX insert and inhibition of channel activity. Interestingly, presence of the STREX insert also appears to prevent the inhibitory effect of protein kinase $\mathrm{C}$ (PKC) on $\mathrm{BK}$ channel opening, possibly by inducing a conformation that precludes PKC-induced phosphorylation of Ser695 within the linker joining RCK1 and RCK2 domains (Zhou et al., 2012).

In addition to Ser/Thr phosphorylation, BK channels also undergo direct Tyr phosphorylation in the presence Src family kinases (i.e., c-Src and Hck) and the $\mathrm{Ca}^{2+}$-sensitive tyrosine kinase Pyk-2 (Ling et al., 2000, 2004; Alioua et al., 2002; Yang et al., 2012). Functionally, direct tyrosine phosphorylation of the $\mathrm{BK} \alpha$ subunit has been reported to either increase (Ling et al., 2000, 2004; Yang et al., 2012) or decrease (Alioua et al., 2002) channel activity, although the reason(s) for this discrepancy remains unclear. Work from our group has shown that Phe substitution of Tyr766 in the C-terminus largely inhibits c-Srcinduced $\mathrm{BK} \alpha$ subunit phosphorylation, but does not appear to disrupt Pyk-2 mediated modification (Ling et al., 2000, 2004). Future studies examining the direct phosphorylation of native BK channels by tyrosine kinases in situ are needed to clarify the physiologic importance of this regulatory event.

\section{ENDOGENOUS REGULATORY MOLECULES}

Endogenous molecules (e.g., heme, carbon monoxide (CO), reactive oxygen species) have been reported to interact with the BK channel complex (for review, see Hou et al., 2009). Similarly, acidification of the cytosol (i.e., $\mathrm{pH}$ 6.5) is able to increase BK channel activation by left-shifting the voltage dependence by $\sim 45 \mathrm{mV}$, but such effects can be readily masked by physiological levels of free $\mathrm{Mg}^{2+}$ (i.e., $1 \mathrm{mM}$ ) and $\mathrm{Ca}^{2+}$ (i.e., $1 \mu \mathrm{M}$ ) (Avdonin et al., 2003). The importance of $\left[\mathrm{H}^{+}\right]$with regards to $\mathrm{BK}$ channel activity may become more apparent during pathological conditions where fluctuations in $\left[\mathrm{H}^{+}\right]$and $\left[\mathrm{Ca}^{2+}\right]$ may occur (e.g., cerebral ischemia) (Lipton, 1999).

The linker between the RCK1 and RCK2 regions of the $\mathrm{BK} \alpha$ subunit (Figure 1) reportedly contains a binding site for intracellular heme molecules (Hou et al., 2009). Application of heme to the cytosolic face of BK channels was found to inhibit channel opening with an $\mathrm{IC}_{50} \sim 70 \mathrm{nM}$ (Tang et al., 2003), likely via an allosteric process. Moreover, the direction of gating modulation by heme appears to be closely-linked to membrane potential, as $\mathrm{BK}$ channel $\mathrm{P}_{\mathrm{o}}$ is enhanced at negative membrane potentials and inhibited at positive potentials. Heme regulators, transporters and degradation products (e.g., CO) are currently under investigation for their therapeutic potential in influencing BK channel activity and thus, global membrane potential (Hou et al., 2009).

Soluble guanylyl cyclase (sGC) contains an iron (heme) center that serves to bind $\mathrm{NO}$, however, this site is also targeted by $\mathrm{CO}$, which can activate sGC, leading to increased cytosolic [cGMP], PKG activation and enhanced BK channel activity (see Figure 2B). It has been further suggested that CO, along with NO, can also directly augment BK channel activity when applied at sufficiently-high concentrations (Hou et al., 2009; Leffler et al., 2011). Further examination of the physiologic contribution of such effects to BK channel regulation are warranted.

Reactive oxygen species (ROS) that are reported to influence BK channel behavior include hydrogen peroxide $\left(\mathrm{H}_{2} \mathrm{O}_{2}\right)$, superoxide $\left(\mathrm{O}_{2}^{-}\right)$and peroxynitrite $\left(\mathrm{ONOO}^{-}\right)$. Increased levels of ROS may occur under localized conditions, such as atherosclerosis (Li and Förstermann, 2009) and are particularly troublesome, as $\mathrm{H}_{2} \mathrm{O}_{2}$ and $\mathrm{O}_{2}^{-}$will react with free $\mathrm{NO}$ to generate $\mathrm{ONOO}^{-}$, thereby reducing $\mathrm{NO}$ bioavailability and $\mathrm{cGMP} / \mathrm{PKG}$ signaling in vascular smooth muscle. For detailed discussions on impact of ROS on BK channel activity, the reader is referred to excellent review articles (Tang et al., 2004; Hou et al., 2009).

\section{REGULATION OF BK CHANNEL EXPRESSION BY UBIOUITINATION}

Protein ubiquitination has emerged as a ubiquitous quality control mechanism for the regulation of protein trafficking and turnover and has been implicated in the dynamic control of diverse cellular processes (e.g., gene transcription, synaptic development and plasticity, oncogenesis, etc.) (Hershko and Ciechanover, 1998). Protein ubiquitination functions as a tagging system to mark proteins for degradation by the $26 \mathrm{~S}$ proteasome complex and the human genome is reported to contain $>600$ genes encoding E3 ubiquitin ligases (Li et al., 2008), the enzyme responsible for conjugating ubiquitin monomers to target substrates. Given this level of abundance, the ubiquitin-proteasome system (UPS) appears to enzymatically parallel protein phosphorylation, for which $\sim 520$ putative kinase genes have been described (Manning et al., 2002), as a widespread mechanism for protein modification and the regulation of cellular function. Recent evidence indicates that BK channels also undergo ubiquitination, which appears to have important functional implications. In the CNS, interaction of BK channels with cereblon (Jo et al., 2005), a substrate receptor for the CRL4A E3 ligase, leads to ubiquitination of the $\mathrm{BK} \alpha$ subunit and retention of modified channels in the endoplasmic reticulum (Liu et al., 2014). Preventing ubiquitination of BK channels by pharmacologic or genetic interference of the CRL4A enzyme complex leads to increased trafficking of BK channels to the neuronal cell membrane and a higher incidence of seizure induction and epilepsy in mice. Such data point to ubiquitination as an important quality control mechanism to limit BK channel expression in neurons, which will ultimately impact membrane excitability. Given that cereblon transcripts 


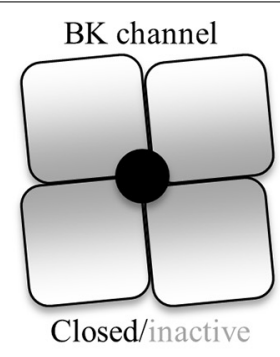

Closed/inactive
$\left[\mathrm{Ca}^{2+}\right] \downarrow, \mathrm{E}_{\mathrm{m}} \uparrow$, STREX phosphorylation, [heme $]_{\mathrm{i}}$ PKC-mediated phosphorylation of $\mathrm{BK} \alpha$ subunit Ser695 \& 1151, BK $\beta 2-3$ subunits.

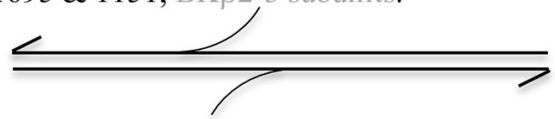

$\left[\mathrm{Ca}^{2+}\right] \uparrow, \mathrm{E}_{\mathrm{m}} \downarrow$, STREX dephosphorylation, PKGmediated phosphorylation of $\mathrm{BK} \alpha$ subunit Ser 691, 873 \&1111-1113, BK $\beta 1,4$ subunits, BK $\gamma$ subunits.

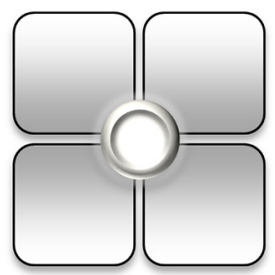

Open/active

FIGURE 3 | A summary of cellular events/factors leading to BK channel activation (open pore) and deactivation/inactivation (closed pore). Abbreviations: $E_{m}$, membrane potential; STREX, stress-axis regulated exon; PKC, protein kinase C; Ser, serine.

are also widely expressed in tissues outside the CNS, this regulatory paradigm may have broader functional importance. As noted above, disruption of the neuronal chaperone CSP $\alpha$ in mice also elevates BK channel expression, suggesting that increased channel density be a common contributing factor to excitation-related neuropathologies.

In VSM, BK $\beta 1$ subunits are reported to undergo ubiquitination in cultured myocytes exposed to high glucose and in arteries obtained from mice made diabetic by injection of streptozotocin, a pancreatic $\beta$-cell poison. Diabetes-like conditions elevate the expression of a muscle-specific RING finger E3 ubiquitin ligase via enhanced NF- $\mathrm{BB}$ transcriptional activity, leading to increased BK $\beta 1$ subunit ubiquitination and proteolysis (Yi et al., 2014). As previously described, loss of the BK $\beta 1$ subunit would be expected to decrease $\mathrm{Ca}^{2+}$ - and voltage-dependent activation of VSM BK channels (Brenner et al., 2000b), leading to exaggerated membrane depolarization and smooth muscle contraction. As $B K \beta 1$ subunits may be capable of dynamically assembling with $\mathrm{BK} \alpha$ subunits at the membrane (Leo et al., 2014), ubiquitination of $\mathrm{BK} \beta 1$ alone may not necessarily result in a decreased cellular level of $\mathrm{BK} \alpha$ subunits.

\section{CONCLUDING REMARKS}

BK channel activity is regulated both directly and indirectly through a diverse range of modulatory pathways involving covalent modifications, metabolic factors, trafficking events and transcriptional processes (see Figure 3). Given the formidable effect that BK channels can exert on membrane excitability, as a result of their large single channel conduction and dual activation by membrane depolarization/cytosolic free $\mathrm{Ca}^{2+}$, such "fine-tuning" affords cells the ability to precisely control the impact of these channels on their function and responsiveness to both acute and chronic stimuli. As reinforced by the accompanying articles in this thematic issue, BK channels represent powerful effectors in tissue health and dysfunction and that understanding their modes of regulation may lead to novel therapeutic strategies in disease treatment.

\section{ACKNOWLEDGMENTS}

This work was supported by research funding to APB from the Canadian Institutes of Health Research and the Natural Sciences and Engineering Research Council.

\section{AUTHOR NOTE}

Lingle and coworkers have demonstrated that the $\gamma 1$ subunit (i.e., LRRC26) mediated leftward shift in BK channel gating occurs in an all-or-none fashion, in contrast to the incremental shifts in gating produced by stoichiometric association of BK $\beta 1$ subunits (Proc. Natl. Acad. Sci. U.S.A. 111, 4873, 2014. doi: 10.1073/pnas.1322123111). Subsequently, Evanson et al. (2014) have reported that LRRC26 is endogenously expressed in rat cerebral vascular myocytes and may function as an auxiliary $\gamma 1$ subunit by altering the voltage and calcium sensitivity of BK channel gating (Circ. Res. 115, 423-431. doi: 10.1161/CIRCRESAHA. 115.303407).

\section{REFERENCES}

Ahrendt, E., Kyle, B. D., Braun, A. P., and Braun, J. E. (2014). Cysteine string protein limits express of the large conductance, calcium-activated $\mathrm{K}^{+}(\mathrm{BK})$ channel. PLoS ONE 9:e86586. doi: 10.1371/journal.pone.0086586

Alioua, A., Lu, R., Kumar, Y., Eghbali, M., Kundu, P., Toro, L., et al. (2008). Slo1 caveolin-binding motif, a mechanism of caveolin-1-Slo1 interaction regulating Slo1 surface expression. J. Biol. Chem. 283, 4808-4817. doi: 10.1074/jbc.M709802200

Alioua, A., Mahajan, A., Nishimaru, K., Zarei, M. M., Stefani, E., and Toro, L. (2002). Coupling of c-Src to large conductance voltage- and $\mathrm{Ca}^{2+}$-activated $\mathrm{K}^{+}$ channels as a new mechanism of agonist-induced vasoconstriction. Proc. Natl. Acad. Sci. U.S.A. 99, 14560-14565. doi: 10.1073/pnas.222348099

Amberg, G. C., Bonev, A. D., Rossow, C. F., Nelson, M. T., and Santana, L. F. (2003). Modulation of the molecular composition of large conductance, $\mathrm{Ca}^{2+}$ activated $\mathrm{K}^{+}$channels in vascular smooth muscle hypertension. J. Clin. Invest. 112, 717-724. doi: 10.1172/JCI200318684

Amberg, G. C., and Santana, L. F. (2003). Downregulation of the BK channel $\beta 1$ subunit in genetic hypertension. Circ. Res. 93, 965-971. doi: 10.1161/01.RES.0000100068.43006.36

Avdonin, V., Tang, X. D., and Hoshi, T. (2003). Stimulatory action of internal protons on Slo1 BK channels. Biophys. J. 84, 2969-2980. doi: 10.1016/S00063495(03)70023-X

Aydin, M., Wang, H. Z., Zhang, X., Chua, R., Downing, K., Melman, A., et al. (2012). Large-conductance calcium-activated potassium channel activity, as determined by whole-cell patch clamp recording, is decreased in urinary bladder smooth muscle cells from male rats with partial urethral obstruction. BJU Int. 110, E402-E408. doi: 10.1111/j.1464-410X.2012. 11137.x

Bielefeldt, K., and Jackson, M. B. (1993). A calcium-activated potassium channel causes frequency-dependent action potential failures in a mammalian nerve terminal. J. Neurophysiol. 70, 284-298.

Brenner, R., Chen, Q. H., Vilaythong, A., Toney, G. M., Noebels, J. L., and Aldrich, R. W. (2005). BK channel $\beta 4$ subunit reduces dentate gyrus excitability and protects against temporal lobe seizures. Nat. Neurosci. 8, 1752-1759. doi: $10.1038 / \mathrm{nn} 1573$ 
Brenner, R., Jegla, T. J., Wickenden, A., Liu, Y., and Aldrich, R. W. (2000a). Cloning and functional characterization of novel large conductance calcium-activated potassium channel $\beta$ subunits, hKCNMB3 and hKCNMB4. J. Biol. Chem. 275, 6453-6461. doi: 10.1074/jbc.275.9.6453

Brenner, R., Perez, G., Bonev, A. D., Eckman, D. M., Kosek, J. C., Wiler, S. W., et al. (2000b). Vasoregulation by the $\beta 1$ subunit of the calcium-activated potassium channel. Nature 407, 870-876. doi: 10.1038/35038011

Burdyga, T., and Wray, S. (2005). Action potential refractory period in ureter smooth muscle is set by Ca sparks and BK channels. Nature 436, 559-562. doi: 10.1038 /nature03834

Chang, S., Gomes, C. M., Hypolite, J. A., Marx, J., Alanzi, J., Zderic, S. A., et al. (2010). Detrusor overactivity is assoicated with downregulation of largeconductance calcium- and voltage-activated potassium channel protein. Am. J. Physiol. Renal Physiol. 298, F1416-F1423. doi: 10.1152/ajprenal.00595.2009

Christ, G. J., and Hodges, S. (2006). Molecular mechanisms of detrusor and corporal myocyte contraction: identifying tragets for pharmacotherapy of bladder and erectile dysfunction. Br. J. Pharmacol. 147, S41-S55. doi: 10.1038/sj.bjp.0706627

Contreras, G. F., Neely, A., Alvarez, O., Gonzalez, C., and Latorre, R. (2012). Modulation of BK channel voltage gating by different auxiliary $\beta$ subunits. Proc. Natl. Acad. Sci. U.S.A. 109, 18991-18996. doi: 10.1073/pnas.1216953109

Cui, J., Yang, H., and Lee, U. S. (2009). Molecular mechanisms of BK channel activation. Cell. Mol. Life Sci. 66, 852-875. doi: 10.1007/s00018-008-8609-x

Davis, M. J., Wu, X., Nurkiewicz, T. R., Kawasaki, J., Gui, P., Hill, M. A., et al. (2001). Regulation of ion channels by protein tyrosine phosphorylation. Am. J. Physiol. 281, H1835-H1862.

Donnelier, J., and Braun, J. E. (2014). CSP $\alpha$ - Chaperoning presynaptic proteins. Front. Cell. Neurosci. 8:116. doi: 10.3389/fncel.2014.00116

Du, W., Bautista, J. F., Yang, H., Diez-Sampdero, A., You, S. A., Wang, L., et al. (2005). Calcium-sensitive potassium channelopathy in human epilepsy and paroxysmal movement disorder. Nat. Genet. 7, 733-738. doi: 10.1038/ng1585

England, S. K., Wooldridge, T. A., Stekiel, W. J., and Rusch, N. J. (1993). Enhanced single-channel $\mathrm{K}^{+}$current in arterial membranes from genetically hypertensive rats. Am. J. Physiol. Heart Circ. Physiol. 264, H1337-H1345.

Faber, E. S., and Sah, P. (2003). Calcium-activated potassium channels: multiple contributions to neuronal function. Neuroscientist 9, 181-194. doi: $10.1177 / 1073858403009003011$

Fakler, B., and Adelman, J. P. (2008). Control of $\mathrm{K}_{\mathrm{Ca}}$ channels by calcium nano/microdomains. Neuron 59, 873-881. doi: 10.1016/j.neuron.2008.09.001

Feil, R., Lohmann, S. M., De Jonge, H. R., Walter, U., and Hofmann, F. (2003). Cyclic GMP-dependent protein kinases and the cardiovascular system: insights from genetically modified mice. Circ. Res. 93, 907-916. doi: 10.1161/01.RES.0000100390.68771.CC

Fernandez-Chacon, R., Wolfel, M., Nishimune, H., Tabares, L., Schmitz, F., Castellano-Munoz, M., et al. (2004). The synaptic vesicle protein $\operatorname{CSP} \alpha$ prevents presynaptic degeneration. Neuron 42, 237-251. doi: 10.1016/S08966273(04)00190-4

Fernández-Fernández, J. M., Tomás, M., Vázquez, E., Orlo, P., Latorre, R., Senti, M., et al. (2004). Gain-of-function mutation in the KCNMB1 potassium channel subunit is associated with low prevalence of diastolic hypertension. J. Clin. Invest. 113, 1032-1039. doi: 10.1172/JCI200420347

Fleming, I., and Busse, R. (2003). Molecular mechanisms involved in the regulation of the endothelial nitric oxide synthase. Am. J. Physiol. Regul. Integr. Comp. Physiol. 284, R1-R12. doi: 10.1152/ajpregu.00323.2002

Francis, S. H., Busch, J. L., and Corbin, J. D. (2010). cGMP-dependent protein kinases and cGMP phosphodiesterases in nitric oxide and cGMP action. Pharmacol. Rev. 62, 525-563. doi: 10.1124/pr.110.002907

$\mathrm{Gu}$, N., Vervaeke, K., and Storm, J. F. (2007). BK potassium channels facilitate high-frequency firing and cause early spike frequency adaptation in rat CAl hippocampal pyramidal cells. J. Physiol. 580, 859-882. doi: 10.1113/jphysiol.2006.126367

Haghdoost-Yazdi, H., Janahmadi, M., and Behzadi, G. (2008). Iberiotoxiinsensitive large conductance $\mathrm{Ca}^{2+}$-dependent $\mathrm{K}^{+}(\mathrm{BK})$ channels regulate the spike configuration in the burst firing of cerebellar Purkinje neurons. Brain Res. 1212, 1-8. doi: 10.1016/j.brainres.2008.03.030

Heppner, T. J., Bonev, A. D., and Nelson, M. T. (1997). $\mathrm{Ca}^{2+}$-activated K ${ }^{+}$channels regulate action potential repolarization in urinary bladder smooth muscle. Am. J. Physiol. Cell Physiol. 273, C110-C117.

Hershko, A., and Ciechanover, A. (1998). The ubiquitin system. Annu. Rev. Biochem. 67, 425-479. doi: 10.1146/annurev.biochem.67.1.425
Hoshi, T., Pantazis, A., and Olcese, R. (2013). Transduction of voltage and $\mathrm{Ca}^{2+}$ signals by Slo1 BK channels. Physiology 28, 172-189. doi: 10.1152/physiol.00055.2012

Hou, S., Heinemann, S. H., and Hoshi, T. (2009). Modulation of BKCa channel gating by endogenous signaling molecules. Physiology 4, 26-35. doi: 10.1152/physiol.00032.2008

Hristov, K. L., Chen, M., Kellett, W. F., Rovner, E. S., and Petkov, G. V. (2011). Large-conductance voltage- and $\mathrm{Ca}^{2+}$-activated $\mathrm{K}^{+}$channels regulate human detrusor smooth muscle function. Am. J. Physiol. Cell Physiol. 301, C903-C912. doi: 10.1152/ajpcell.00495.2010

Hu, H., Shao, L.-R., Chavoshy, S., Gu, N., Trieb, M., Behrens, R., et al. (2001). Presynaptic $\mathrm{Ca}^{2+}$-activated $\mathrm{K}^{+}$channels in glutamatergic hippocampal terminals and their role in spike repolarization and regulation of transmitter release. J. Neurosci. 21, 9585-9597.

Imlach, W. L., Finch, S. C., Dunlop, J., Meredith, A. L., Aldrich, R. W., and Dalziel, J. E. (2008). The molecular mechanims of "ryegrass staggers," a neurological disorder of $\mathrm{K}^{+}$channels. J. Pharmacol. Exp. Ther. 327, 657-664. doi: 10.1124/jpet.108.143933

Issa, N. P., and Hudspeth, A. J. (1994). Clustering of $\mathrm{Ca}^{2+}$ channels and $\mathrm{Ca}^{2+}$ activated $\mathrm{K}^{+}$channels at fluorescently labeled presynaptic active zones of hair cells. Proc. Natl. Acad. Sci. U.S.A. 91, 7578-7582. doi: 10.1073/pnas.91. 16.7578

Jo, S., Lee, K.-H., Song, S., Jung, Y.-K., and Park, C.-S. (2005). Identification and functional characterization of cereblon as a binding protein for largeconductance calcium-activated potassium channel in rat brain. J. Neurochem. 94, 1212-1224. doi: 10.1111/j.1471-4159.2005.03344.x

Johnson, B. E., Glauser, D. A., Dan-Glauser, E. S., Halling, B., Aldrich, R. W., and Goodman, M. B. (2011). Alternatively spliced domains interact to regulate BK potassium channel gating. Proc. Natl. Acad. Sci. U.S.A. 108, 20784-20789. doi: 10.1073/pnas.1116795108

Joseph, B. K., Thakali, K. M., Moore, C. L., and Rhee, S. W. (2013). Ion channel remodeling in vascular smooth muscle during hypertension: implications for novel therapeutic approaches. Pharmacol. Res. 70, 126-138. doi: 10.1016/j.phrs.2013.01.008

Kaczorowski, G. J., and Garcia, M. L. (1999). Pharmacology of voltage-gated and calcium-activated potassium channels. Curr. Opin. Chem. Biol. 3, 448-458. doi: 10.1016/S1367-5931(99)80066-0

Knaus, H.-G., Folander, K., Garcia-Calvo, M., Garcia, M. L., Kaczorowski, G. J., Smith, M., et al. (1994a). Primary sequence and immunological characterization of $\beta$-subunit of high conductance $\mathrm{Ca}^{2+}$-activated $\mathrm{K}^{+}$channel from smooth muscle. J. Biol. Chem. 269, 17274-17278.

Knaus, H.-G., McManus, O. B., Lee, S. H., Schmalhofer, W. A., Garcia-Calvo, M., Helms, L. M., et al. (1994b). Tremorogenic indole alkaloids potentialy inhibit smooth muscle high-conductance calcium-activated potassium channels. Biochem 33, 5819-5828. doi: 10.1021/bi00185a021

Kyle, B. D., Ahrendt, E., Braun, A. P., and Braun, J. E. (2013a). The large conductance, calcium-activated $\mathrm{K}^{+}(\mathrm{BK})$ channel is regulated by cysteine string protein. Sci. Rep. 3:2447. doi: 10.1038/srep02447

Kyle, B. D., Bradley, E., Large, R., Sergeant, G. P., McHale, N. G., Thornbury, K. D., et al. (2013b). Mechanisms underlying activation of transient BK current in rabbit urethral smooth muscle cells and its modulation by $\mathrm{IP}_{3}$-generating agonists. Am. J. Physiol. Cell Physiol. 305, C609-C622. doi: 10.1152/ajpcell.00025.2013

Kyle, B. D., Hurst, S., Swayze, R. D., Sheng, J.-Z., and Braun, A. P. (2013c). Specific phosphorylation sites underlie the stimulation of a large conductance, $\mathrm{Ca}^{2+}$-activated $\mathrm{K}^{+}$channel by cGMP-dependent protein kinase. FASEB J. 27, 2027-2038. doi: 10.1096/fj.12-223669

Latorre, R., Oberhauser, A., Labarca, P., and Alvarez, O. (1989). Varieties of calcium-activated potassium channels. Annu. Rev. Physiol. 51, 385-399. doi: 10.1146/annurev.ph.51.030189.002125

Leffler, C. W., Parfenova, H., and Jaggar, J. H. (2011). Carbon monoxide as an endogenous vascular modulator. Am. J. Physiol. Heart Circ. Physiol. 301, H1-H11. doi: 10.1152/ajpheart.00230.2011

Leo, M. D., Bannister, J. P., Narayanan, D., Nair, A., Grubbs, J. E., Gabrick, K. S., et al. (2014). Dynamic regulation of $\beta 1$ subunit trafficking controls vascular contractility. Proc. Natl. Acad. Sci. U.S.A. 111, 2361-2366. doi: $10.1073 /$ pnas. 1317527111

Li, H., and Förstermann, U. (2009). Prevention of atherosclerosis by interference with the vascular nitric oxide system. Curr. Pharm. Des. 15, 3133-3145. doi: $10.2174 / 138161209789058002$ 
Li, W., Bengston, M. H., Ulbrich, A., Matsuda, A., Reddy, V. A., Orth, A., et al. (2008). Genome-wide and functional annotation of human E3 ubiquitin ligases identifies MULAN, a mitochondrial E3 that regulates the organelle's dynamics and signaling. PLoS ONE 3:e1487. doi: 10.1371/journal.pone.0001487

Lin, M. T., Hessinger, D. A., Pearce, W. J., and Longo, L. D. (2006). Modulation of BK channel calcium affinity by differential phosphorylation in developing ovine basilar artery myocytes. Am. J. Physiol. Heart Circ. Physiol. 291, H732-H740. doi: 10.1152/ajpheart.01357.2005

Lin, M. T., Longo, L. D., Pearce, W. J., and Hessinger, D. A. (2005). $\mathrm{Ca}^{2+}$ activated $\mathrm{K}^{+}$channel-associated phosphatase and kinase activities during development. Am. J. Physiol. Heart Circ. Physiol. 289, H414-H425. doi: 10.1152/ajpheart.01079.2004

Ling, S., Sheng, J.-Z., and Braun, A. P. (2004). The calcium-dependent activity of large-conductance, calcium-activated $\mathrm{K}^{+}$channels is enhanced by Pyk2and Hck-induced tyrosine phosphorylation. Am. J. Physiol. Cell Physiol. 287, C698-C706. doi: 10.1152/ajpcell.00030.2004

Ling, S., Woronuk, G., Sy, L., Lev, S., and Braun, A. P. (2000). Enhanced activity of a large conductance, calcium-sensitive $\mathrm{K}^{+}$channel in the presence of Srctyrosine kinase. J. Biol. Chem. 275, 30683-30689. doi: 10.1074/jbc.M004292200

Lipton, P. (1999). Ischemic cell death in brain neurons. Physiol. Rev. 79, 1431-1568.

Liu, G., Zakharov, S. I., Yang, L., Wu, R. S., Deng, S. X., Landry, D. W., et al. (2008). Locations of the $\beta 1$ transmembrane helices in the BK potassium channel. Proc. Natl. Acad. Sci. U.S.A. 105, 10727-10732. doi: 10.1073/pnas.0805212105

Liu, J., Ye, J., Zou, X., Xu, Z., Feng, Y., Zou, X., et al. (2014). CRL4A ${ }^{\text {CRBN }}$ E3 ubiquitin ligase restricts $\mathrm{BK}$ channel activity and prevents epileptogenesis. Nat. Commun. 5:3924. doi: 10.1038/ncomms4924

Liu, Y., Hudetz, A. G., Knaus, H.-G., and Rusch, N. J. (1998). Increased expression of $\mathrm{Ca}^{2+}$-sensitive $\mathrm{K}^{+}$channels in the cerebral microcirculation of genetically hypertensive rats. evidence for their protection against cerebral vasospasm. Circ. Res. 82, 729-737. doi: 10.1161/01.RES.82.6.729

Ma, Z., Lou, X. J., and Horrigan, F. T. (2006). Role of charged residues in the S1-S4 voltage sensor of BK channels. J. Gen. Physiol. 127, 309-328. doi: 10.1085/jgp.200509421

Manning, G., Whyte, D. B., Martinez, R., Hunter, T., and Sudarsanam, S. (2002). The protein kinase complement of the human genome. Science 298, 1912-1934. doi: $10.1126 /$ science.1075762

Marrion, N. V., and Tavalin, S. J. (1998). Selective activation of $\mathrm{Ca}^{2+}$-activated $\mathrm{K}^{+}$ channels by co-localized $\mathrm{Ca}^{2+}$ channels in hippocampal neurons. Nature 395, 900-905. doi: 10.1038/27674

Meredith, A. L., Thorneloe, K. S., Werner, M. E., Nelson, M. T., and Aldrich, R. W. (2004). Overactive bladder and incontinence in the absence of the BK large conductance $\mathrm{Ca}^{2+}$-activated $\mathrm{K}^{+}$channel. J. Biol. Chem. 279, 36746-36752. doi: 10.1074/jbc.M405621200

Morera, F., Alioua, A., Kundu, P., Salazar, M., Gonzalez, C., Martinez, A. D., et al. (2012). The first transmembrane domain (TM1) of $\beta 2$-subunit binds to the transmembrane domain S1 of $\alpha$-subunit in BK potassium channels. FEBS Lett. 586, 2287-2293. doi: 10.1016/j.febslet.2012.05.066

Morrow, J. P., Zakharov, S. I., Liu, G., Yang, L., Sok, A. J., and Marx, S. O. (2006). Defining the BK channel domains required for $\beta 1$-subunit modulation. Proc. Natl. Acad. Sci. U.S.A. 103, 5096-5101. doi: 10.1073/pnas.0600907103

Münzel, T., Feil, R., Mülsch, A., Lohmann, S. M., Hofmann, F., and Walter, U. (2003). Physiology and pathophysiology of vascular signaling controlled by cyclic guanosine $3^{\prime}, 5^{\prime}$-cyclic monophosphate-dependent protein kinase. Circulation 108, 2172-2183. doi: 10.1161/01.CIR.0000094403.78467.C3

Nara, M., Dhulipala, P. D., Wang, Y. X., and Kotlikoff, M. I. (1998). Reconstitution of $\beta$-adrenergic modulation of large conductance, calcium-activated potassium (Maxi-K) channels in Xenopus oocytes. J. Biol. Chem. 273, 14920-14924. doi: 10.1074/jbc.273.24.14920

Nardi, A., and Olesen, S. P. (2008). BK channel modulators: a comprehensive overview. Curr Med. Chem. 15, 1126-1146. doi: 10.2174/092986708784221412

Nielsen, T., Sølvsten Burgdorf, K., Grarup, N., Borch-Johnsen, K., Hansen, T., Jørgensen, T., et al. (2008). The KCNMB1 Glu65Lys polymorphism associates with reduced systolic and diastolic blodd pressure in the Inter99 study of 5729 Danes. J. Hypertension 26, 2142-2146. doi: 10.1097/HJH.0b013e32830b894a

Nieves-Cintrón, M., Amberg, G. C., Nichols, C. B., Molkentin, J. D., and Santana, L. F. (2007). Activation of NFATc3 down-regulates the $\beta 1$ subunit of large conductance, calcium-actiated $\mathrm{K}^{+}$channels in arterial smooth muscle and contributes to hypertension. J. Biol. Chem. 282, 3231-3240. doi: 10.1074/jbc.M608822200
Nourian, Z., Li, M., Leo, M. D., Jaggar, J. H., Braun, A. P., and Hill, M. A. (2014). Large conductance $\mathrm{Ca}^{2+}$-activated $\mathrm{K}^{+}$channel $\left(\mathrm{BK}_{\mathrm{Ca}}\right) \alpha$-subunit splice variants in resistance arteries from rat cerebral and skeletal muscle vasculature. PLoS ONE 9:e98863. doi: 10.1371/journal.pone.0098863

Oger, S., Behr-Roussel, D., Gorny, D., Bernabé, J., Comperat, E., Chartier-Kastler, E., et al. (2010). Efects of potassium chanel modulators on myogenic spontaneous phasic contractile activity in human detrusor from neurogenic patients. BJU Int. 108, 604-611. doi: 10.1111/j.1464-410X.2010.09935.x

Ohi, Y., Yamamura, H., Nagano, N., Ohya, S., Muraki, K., Watanabe, M., et al. (2001). Local $\mathrm{Ca}^{2+}$ transients and distribution of BK channels and ryanodine receptors in smooth muscle cells of guinea-pig vas deferens and urinary bladder. J. Physiol. 534, 313-326. doi: 10.1111/j.1469-7793.2001.t01-3-00313.x

Ohya, S., Fujimori, T., Kimura, T., Yamamura, H., and Imaizumi, Y. (2010). Novel spliced variants of large-conductance $\mathrm{Ca}^{2+}$-activated $\mathrm{K}^{+}$-channel $\beta 2$-subunit in human and rodent pancreas. J. Pharmacol. Sci. 114, 198-205. doi: 10.1254/jphs.10159FP

Pérez, G. J., Bonev, A. D., Patlak, J. B., and Nelson, M. T. (1999). Functional coupling of ryanodine receptors to $\mathrm{K}_{\mathrm{Ca}}$ channels in smooth muscle cells from rat cerebral arteries. J. Gen. Physiol. 113, 229-237. doi: 10.1085/jgp.113.2.229

Petkov, G. V., Bonev, A. D., Heppner, T. J., Brenner, R., Aldrich, R. W., and Nelson, M. T. (2001). $\beta 1$-Subunit of the $\mathrm{Ca}^{2+}$-activated $\mathrm{K}^{+}$channel regulates contractile activity of mouse urinary bladder smooth muscle. J. Physiol. (Lond.) 537, 443-452. doi: 10.1111/j.1469-7793.2001.00443.x

Plüger, S., Faulhaber, J., Fürstenau, M., Löhn, M., Waldschutz, R., Gollasch, M., et al. (2001). Mice with disrupted BK channel $\beta 1$ subunit gene feature abnormal $\mathrm{Ca}^{2+}$ spark/STOC coupling and elevated blood pressure. Circ. Res. 87, e53-e60. doi: 10.1161/01.RES.87.11.e53

Poulsen, A. N., Wulf, H., Hay-Schmidt, A., Jansen-Olesen, I., Olesen, J., and Klaerke, D. A. (2009). Differential expression of BK channel isoforms and $\beta$ subunits in rat neuro-vascular tissues. Biochim. Biophys. Acta 1788, 380-389. doi: 10.1016/j.bbamem.2008.10.001

Raffaelli, G., Saviane, C., Mohajerani, M. H., Pedarzani, P., and Cherubini, E. (2004). BK potassium channels control transmitter release at CA3-CA3 synapses in rat hippocampus. J. Physiol. 557, 147-157. doi: 10.1113/jphysiol.2004.062661

Reinhart, P. H., Chung, S., Martin, B. L., Brautigan, D. L., and Levitan, I. B. (1991). Modulation of calcium-activated potassium channels from rat brain by protein kinase A and phosphatase 2A. J. Neurosci. 11, 1627-1635.

Reinhart, P. H., and Levitan, I. B. (1995). Kinase and phosphatase activities intimately associated with a reconstituted calcium-dependent potassium channel. J. Neurosci. 15, 4572-4579.

Roberts, W. M., Jacobs, R. A., and Hudspeth, A. J. (1990). Colocalization of ion channels involved in frequency selectivity and synaptic transmission at presynaptic active zones of hair cells. J. Neurosci. 10, 3664-3684.

Robitaille, R., and Charlton, M. P. (1992). Presynaptic calcium signals and transmitter release are modulated by calcium-activated potassium channels. J. Neurosci. 12, 297-305.

Rusch, N. J., De Lucena, R. G., Wooldridge, T. A., England, S. K., and Cowley, A. W. Jr. (1992). A Ca ${ }^{2+}$-dependent $\mathrm{K}^{+}$current is enhanced in arterial membranes of hypertensive rats. Hypertension 19, 301-307. doi: 10.1161/01.HYP.19.4.301

Rusch, N. J., and Runnells, A. M. (1994). Remission of high blood pressure reverses arterial potassium channel alterations. Hypertension 23, 941-945. doi: 10.1161/01.HYP.23.6.941

Sanders, K. M. (2008). Regulation of smooth muscle excitation and contraction. Neurogastroenterol. Motil. 20, 39-53. doi: 10.1111/j.1365-2982.2008.01108.x

Sansom, S. C., Stockand, J. D., Hall, D., and Williams, B. (1997). Regulation of large conductance calcium-activated potassium channels by protein phosphatase $2 \mathrm{~A}$. J. Biol. Chem. 272, 9902-9906. doi: 10.1074/jbc.272.15.9902

Sausbier, M., Hu, H., Arntz, C., Feil, S., Kamm, S., Adelsberger, H., et al. (2004). Cerebellar ataxia and Purkinje cell dysfunction caused by $\mathrm{Ca}^{2+}$-activated $\mathrm{K}^{+}$channel deficiency. Proc. Natl. Acad. Sci. U.S.A. 101, 9474-9478. doi: 10.1073/pnas.0401702101

Schubert, R., and Nelson, M. T. (2001). Protein kinases: tuners of the $\mathrm{BK}_{\mathrm{Ca}}$ channel in smooth muscle. TIPS 22, 505-512. doi: 10.1016/S0165-6147(00)01775-2

Seibold, M. A., Wang, B., Eng, C. E., Kumar, G., Beckman, K. B., Sen, S., et al. (2008). An african-specific functional polymorphism in KCNMB1 shows sex-specific association with asthma severity. Hum. Mol. Genet. 17, 2681-2690. doi: $10.1093 / \mathrm{hmg} / \mathrm{ddn} 168$

Shen, K.-Z., Lagrutta, A., Davies, N. W., Standen, N. B., Adelman, J. P., and North, R. A. (1994). Tetraethylammonium block of Slowpoke calcium-activated 
potassium channels expressed in Xenopus oocytes: evidence for tetrameric channel formation. Pflügers Arch. 426, 440-445. doi: 10.1007/BF00388308

Shipston, M. J. (2001). Alternative splicing of potassium channels: a dynamic switch of cellular excitability. Trends Cell Biol. 11, 353-358. doi: 10.1016/S09628924(01)02068-2

Shipston, M. J. (2014). Ion channel regulation by protein S-acylation. J. Gen. Physiol. 143, 659-678. doi: 10.1085/jgp.201411176

Singh, H., Stefani, E., and Toro, L. (2012). Intracellular $\mathrm{BK}_{\mathrm{Ca}}\left(\mathrm{iBK}_{\mathrm{Ca}}\right)$ channels. J. Physiol. (Lond.) 590, 5937-5947. doi: 10.1113/jphysiol.2011.215533

Sprossmann, F., Pankert, P., Sausbier, U., Wirth, A., Zhou, X.-B., Madlung, J., et al. (2009). Inducible knockout mutagenesis reveals compensatory mechanisms elicited by constitutive BK channel deficiency in overactive murine bladder. FEBS Lett. 276, 1680-1697. doi: 10.1111/j.1742-4658.2009.06900.x

Tanaka, Y., Meera, P., Song, M., Knaus, H.-G., and Toro, L. (1997). Molecular constituents of maxi- $\mathrm{K}_{\mathrm{Ca}}$ channels in human coronary smooth muscle: predominant $\alpha+\beta$ subunit complexes. J. Physiol. (Lond.) 502, 545-557. doi: 10.1111/j.1469-7793.1997.545bj.x

Tang, X. D., Santarelli, L. C., Heinemann, S. H., and Hoshi, T. (2004). Metabolic regulation of potassium channels. Annu. Rev. Physiol. 66, 131-159. doi: 10.1146/annurev.physiol.66.041002.142720

Tang, X. D., Xu, R., Reynolds, M. F., Garcia, M. L., Heinemann, S. H., and Hoshi, T. (2003). Haem can bind to and inhibit mammalian calcium-dependent Slo1 BK channels. Nature 425, 531-535. doi: 10.1038/nature02003

Taylor, S. S., Buechler, J. A., and Yonemoto, W. (1990). cAMP-dependent protein kinase: framework for a diverse family of regulatory enzymes. Annu. Rev. Biochem. 59, 971-1005. doi: 10.1146/annurev.bi.59.070190.004543

Thorneloe, K. S., and Nelson, M. T. (2005). Ion channels in smooth muscle: regulators of intracellular calcium and contractility. Can. J. Physiol. Pharmacol. 83, 215-242. doi: 10.1139/y05-016

Tian, L., Coghill, L. S., McClafferty, H., MacDonald, S. H., Antoni, F. A., Ruth, P., et al. (2004). Distinct stoichiometry of BKCa channel tetramer phosphorylation specifies channel activation and inhibition by cAMP-dependent protein kinase. Proc. Natl. Acad. Sci. U.S.A. 101, 11897-11902. doi: 10.1073/pnas.0402590101

Tian, L., Duncan, R. R., Hammond, M. S., Coghill, L. S., Wen, H., Rusinova, R., et al. (2001). Alternative splicing switches potassium channel sensitivity to protein phosphorylation. J. Biol. Chem. 276, 7717-7720. doi: 10.1074/jbc.C000741200

Tian, L., Jeffries, O., McClafferty, H., Molyvdas, A., Rowe, I. C., Saleem, F., et al. (2008). Palmitoylation gates phosphorylation-dependent regulation of BK potassium channels. Proc. Natl. Acad. Sci. U.S.A. 105, 21006-21011. doi: 10.1073/pnas.0806700106

Tian, L., Knaus, H.-G., and Shipston, M. J. (1998). Glucocorticoid regulation of calcium-activated potassium channels mediated by serine/threonine protein phosphatase. J. Biol. Chem. 273, 13531-13536. doi: 10.1074/jbc.273.22.13531

Toro, B., Cox, N., Wilson, R. J., Garrido-Sanabria, E., Stefani, E., Toro, L., et al. (2006). KCNMB1 regulates surface expression of a voltage and $\mathrm{Ca}^{2+}$-activated $\mathrm{K}^{+}$channel via endocytic trafficking signals. Neuroscience 142, 661-669. doi: 10.1016/j.neuroscience.2006.06.061

Uebele, V. N., Lagrutta, A., Wade, T., Figueroa, D. J., Liu, Y., McKenna, E., et al. (2000). Cloning and functional expression of two families of $\beta$-subunits of the large conductance calcium-activated $\mathrm{K}^{+}$channel. J. Biol. Chem. 275, 23211-23218. doi: 10.1074/jbc.M910187199

Wallner, M., Meera, P., and Toro, L. (1999). Molecular basis f fast inactivation in voltage and $\mathrm{Ca}^{2+}$-activated $\mathrm{K}^{+}$channels: a tranmembrane $\beta$-subunit homolog. Proc. Natl. Acad. Sci. U.S.A. 96, 4137-4142. doi: 10.1073/pnas.96.7.4137

Wang, B., Rothberg, B. S., and Brenner, R. (2006). Mechanism of $\beta 4$ subunit modulation of BK channels. J. Gen. Physiol. 127, 449-465. doi: 10.1085/jgp.200509436

Wang, B., Rothberg, B. S., and Brenner, R. (2009). Mechanism of increased BK channel activation from a channel mutation that causes epilepsy. J. Gen. Physiol. 133, 283-294. doi: 10.1085/jgp.200810141

Wimalawansa, S. (2008). Nitric oxide: new evidence for novel therapeutic indications. Expert Opin. Pharmacother. 9, 1935-1954. doi: 10.1517/14656566.9. 11.1935

Xie, J., and McCobb, D. P. (1998). Control of alternative splicing of potassium channels by stress hormones. Science 280, 443-446. doi: 10.1126/science.280.5362.443

Yan, J., and Aldrich, R. W. (2010). LRRC26 auxiliary protein allow BK channel activation at resting voltage without calcium. Nature 466, 513-517. doi: 10.1038 /nature09162
Yan, J., and Aldrich, R. W. (2012). BK potassium channel modulation by leucinerich repeat-containing proteins. Proc. Natl. Acad. Sci. U.S.A. 109, 7917-7922. doi: 10.1073/pnas.1205435109

Yan, J., Olsen, J. V., Park, K. S., Li, W., Bildl, W., Schulte, U., et al. (2008). Profiling the phospho-status of the $\mathrm{BK}_{\mathrm{Ca}}$ channel $\alpha$ subunit in rat brain reveals unexpected patterns and complexity. Mol. Cell. Proteomics 7, 2188-2198. doi: 10.1074/mcp.M800063-MCP200

Yang, J., Krishnamoorthy, G., Saxena, A., Zhang, G., Shi, J., Yang, H., et al. (2010). An epilepsy/dyskinesia-associated mutation enhances BK channel activation by potentiating $\mathrm{Ca}^{2+}$ sensing. Neuron 66, 871-883. doi: 10.1016/j.neuron.2010.05.009

Yang, Y., Li, P.-Y., Cheng, J., Mao, L., Wen, J., Tan, X.-Q., et al. (2013). Function of $\mathrm{BK}_{\mathrm{Ca}}$ channels is reduced in human vascular smooth muscle cells from Han Chinese patients with hypertension. Hypertension 61, 519-525. doi: 10.1161/HYPERTENSIONAHA.111.00211

Yang, Y., Murphy, T. V., Ella, S. R., Grayson, T. H., Haddock, R., Hwang, Y. T., et al. (2009). Heterogeneity in function of small artery smooth muscle $\mathrm{BK}_{\mathrm{Ca}}$ : involvement of the $\beta 1$-subunit. J. Physiol. (Lond.) 587, 3025-3044. doi: 10.1113/jphysiol.2009.169920

Yang, Y., Wu, X., Gui, P., Wu, J., Sheng, J.-Z., Ling, S., et al. (2012). $\alpha 5 \beta 1$ integrin engagement increases large conductance, $\mathrm{Ca}^{2+}$-activated $\mathrm{K}^{+}$channel current and $\mathrm{Ca}^{2+}$ sensitivity through cSrc-mediated channel phosphorylation. J. Biol. Chem. 285, 131-141. doi: 10.1074/jbc.M109.033506

Yi, F., Wang, H., Chai, Q., Wang, X., Shen, W.-K., Willis, M., et al. (2014). Regulation of large conducatnce $\mathrm{Ca}^{2+}$-activated $\mathrm{K}^{+}(\mathrm{BK})$ channel $\beta 1$ subunit expression by muscle RING finger protein 1 in diabetic vessels. J. Biol. Chem. 289, 10853-10864. doi: 10.1074/jbc.M113.520940

Yuan, P., Leonetti, M. D., Hsiung, Y., and MacKinnon, R. (2012). Open structure of the $\mathrm{Ca}^{2+}$ gating ring in the high-conductance $\mathrm{Ca}^{2+}$-activated $\mathrm{K}^{+}$channel. Nature 481, 94-98. doi: 10.1038/nature10670

Yuan, P., Leonetti, M. D., Pico, A., Hsiung, Y., and MacKinnon, R. (2010). Structure of the human $\mathrm{BK}$ channel $\mathrm{Ca}^{2+}$-activation apparatus at $3.0 \AA$ resolution. Science 329, 182-186. doi: 10.1126/science.1190414

Zarei, M. M., Song, M., Wilson, R. J., Cox, N., Colom, L. V., Knaus, H.-G., et al. (2007). Endocytic trafficking signals in KCNMB2 regulate surface expression of a large conductance voltage and $\mathrm{Ca}^{2+}$-activated $\mathrm{K}^{+}$channel. Neuroscience 147 , 80-89. doi: 10.1016/j.neuroscience.2007.04.019

Zhou, X., Wulfsen, I., Korth, M., McClafferty, H., Lukowski, R., Shipston, M. J., et al. (2012). Palmitoylation and membrane association of the stress axis regulated insert (STREX) controls BK channel regulation by protein kinase C. J. Biol. Chem. 287, 32161-32171. doi: 10.1074/jbc.M112.386359

Zhou, X.-B., Ruth, P., Schlossmann, J., Hofmann, F., and Korth, M. (1996). Protein phosphatase $2 \mathrm{~A}$ is essential for the activation of $\mathrm{Ca}^{2+}$-activated $\mathrm{K}^{+}$currents by cGMP-dependent protein kinase in tracheal smooth muscle and chinese hamster ovary cells. J. Biol. Chem. 271, 19760-19767. doi: 10.1074/jbc.271.33.19760

Zhou, X.-B., Wulfsen, I., Utku, E., Sausbier, U., Sausbier, M., Wieland, T., et al. (2010). Dual role of protein kinase C on BK channel regulation. Proc. Natl. Acad. Sci. U.S.A. 107, 8005-8010. doi: 10.1073/pnas.0912029107

ZhuGe, R., Fogarty, K. E., Tuft, R. A., and Walsh, J. V. Jr. (2002). Spontaneous transient outward currents arise from microdomains where $\mathrm{BK}$ channels are exposed to a mean $\mathrm{Ca}^{2+}$ concentration on the order of $10 \mu \mathrm{M}$ during a $\mathrm{Ca}^{2+}$ spark. J. Gen. Physiol. 120, 15-27. doi: 10.1085/jgp.20028571

Conflict of Interest Statement: The authors declare that the research was conducted in the absence of any commercial or financial relationships that could be construed as a potential conflict of interest.

Received: 10 July 2014; accepted: 02 August 2014; published online: 22 August 2014. Citation: Kyle BD and Braun AP (2014) The regulation of BK channel activity by pre- and post-translational modifications. Front. Physiol. 5:316. doi: 10.3389/fphys. 2014.00316

This article was submitted to Membrane Physiology and Membrane Biophysics, a section of the journal Frontiers in Physiology.

Copyright (C) 2014 Kyle and Braun. This is an open-access article distributed under the terms of the Creative Commons Attribution License (CC BY). The use, distribution or reproduction in other forums is permitted, provided the original author(s) or licensor are credited and that the original publication in this journal is cited, in accordance with accepted academic practice. No use, distribution or reproduction is permitted which does not comply with these terms. 